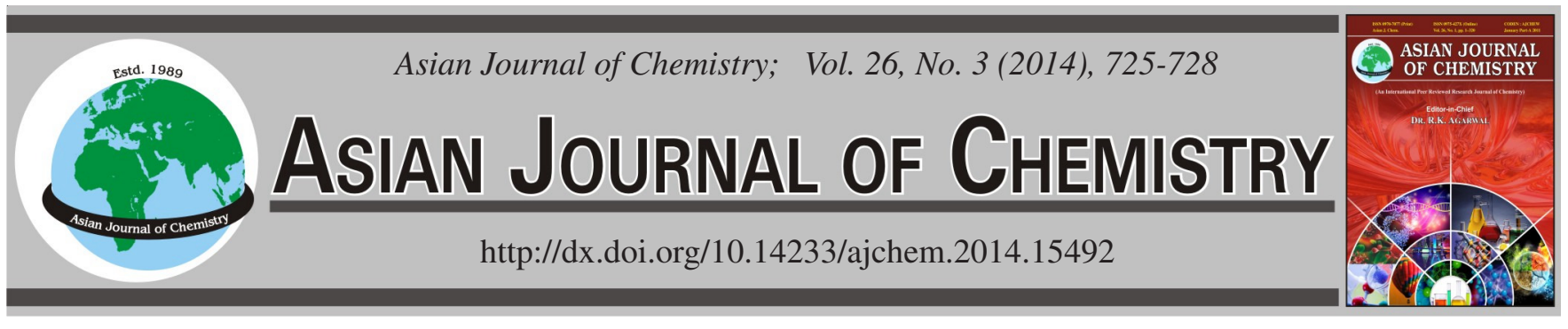

\title{
Thermodynamic and Kinetic Studies of $\alpha$-Amylase Catalyzed Reaction in Free and Carrageenan/Chitosan Immobilized State
}

\author{
Ritchieraj Sarma, Ashoke Kumar Dolui and Atul Kumar*
}

Department of Pharmaceutical Sciences, Dibrugarh University, Dibrugarh-786 004, India

*Corresponding author: E-mail: atul2008@gmail.com

\begin{abstract}
The present study deals with the immobilization of $\alpha$-amylase into carrageenan and chitosan medium and determination of kinetics as well as thermodynamic parameters of both free and immobilized enzyme catalyzed reaction to predict the extent of reaction and the position of equilibrium. At optimized condition, the $\mathrm{K}_{\mathrm{m}}$ value derived from Lineweaver Burk plot for free enzyme $(0.37 \%$ w/v) was lower than the immobilized enzyme $\left(0.48 \% \mathrm{w} / \mathrm{v}\right.$ for carrageenan and $0.59 \% \mathrm{w} / \mathrm{v}$ for chitosan immobilized). The free enzyme had an $\mathrm{E}_{\mathrm{a}}$ value of $1536 \mathrm{cal} / \mathrm{mol} \mathrm{compared} \mathrm{to} \mathrm{those} \mathrm{of} \mathrm{immobilized} \mathrm{enzyme}(5463.8 \mathrm{cal} / \mathrm{mol}$ for carrageenan and $4736 \mathrm{cal} / \mathrm{mol}$ for chitosan immobilized). Computed $\Delta S$ value for free enzyme is more negative than the immobilized enzyme. The increasing value $\Delta \mathrm{G}^{\circ}$ of in immobilized enzyme system indicates that the enzyme-substrate reaction is slower during immobilization. Immobilized enzyme could be reused up to 12 days of storage.
\end{abstract}

Keywords: $\alpha$-Amylase, Kinetics, Enzymes, Immobilization, Carrageenan, Chitosan.

\section{INTRODUCTION}

Almost all processes in a biological cell need enzymes to occur at significant rates. Since enzymes are selective for their substrates and speed up only a few reactions from among many possibilities, the set of enzymes made in a cell determines which metabolic pathways occur in that cell ${ }^{1,2}$. Like all catalysts, enzymes work by lowering the activation energy $\left(E_{a}\right)$ for a reaction, thus dramatically increasing the rate of the reaction.

Enzyme immobilization may be defined as the confinement of an enzyme in a distinct phase to a suitable inert support, where it can act upon its natural substrate repeatedly and continuously and can be renewed conveniently. Immobilization of enzyme molecules does not necessarily render them immobile, in some methods of immobilization e.g., entrapment and membrane confinement, the enzyme molecules move freely within their phase, while in case of adsorption and covalent binding they are in fact immobile. The term immobilization was coined by Katchalskik and Kalzir in 1970. There are various methods of immobilization which include carrier binding (adsorption $^{3}$, ionic binding ${ }^{4}$ and covalent binding ${ }^{5}$ ), cross linking $^{6}$ and entrapment ${ }^{7}$ (gel, fibre and microencapsulation.). In the present study gel entrapment method was chosen to immobilize $\alpha$-amylase in chitosan and carrageenan.

Amylase catalyses the breakdown of starch into sugars. Amylase is present in human saliva, where it begins the chemical process of digestion. The pancreas also makes amylase ( $\alpha$ amylase) to hydrolyze dietary starch into disaccharides and trisaccharides which are converted by other enzymes to glucose to supply the body with energy. $\alpha$-Amylase is one of the largest selling enzymes for a wide variety of industrial applications ${ }^{8}$.

The extent of reaction and the position of equilibrium for any process in which enzyme-catalyzed reactions occur is essentially played by thermodynamic data. Metabolic control analysis requires both thermodynamic and kinetic data ${ }^{9,10}$. It is therefore planned to study the kinetic and thermodynamic aspects of the enzyme substrate reactions using $\alpha$-amylase as model enzyme to determine energy of activation $\left(E_{a}\right)$, Arrhenius factor (A), standard enthalpy change $(\Delta \mathrm{H})$, Gibbs free energy $\left(\Delta \mathrm{G}^{\mathrm{o}}\right)$, standard entropy change $(\Delta \mathrm{S})$, probability factor $(\mathrm{P})$ and equilibrium constant $(\mathrm{K})$ values of enzyme catalyzed reaction for both free and immobilized enzyme using following equations:

$$
\begin{gathered}
\mathrm{k}=A e^{\mathrm{E}_{\mathrm{a}} / \mathrm{RT}} \\
\mathrm{A}=\left(\frac{\mathrm{RT}}{\mathrm{Nh}}\right) \mathrm{e}^{\Delta \mathrm{S} / \mathrm{R}} \\
\mathrm{P}=\mathrm{e}^{\Delta \mathrm{S} / \mathrm{R}} \\
\Delta \mathrm{G}^{\mathrm{o}}=\Delta \mathrm{H}-\mathrm{T} \Delta \mathrm{S} \\
\Delta \mathrm{G}^{\mathrm{o}}=-\mathrm{RT} \ln \mathrm{K} \\
\mathrm{Z}=\frac{\mathrm{RT}}{\mathrm{Nh}}
\end{gathered}
$$




$$
\begin{gathered}
\log \mathrm{k}=\log \mathrm{A}-\frac{\mathrm{E}_{\mathrm{a}}}{2.303} \frac{1}{\mathrm{RT}} \\
\mathrm{k}=\left(\frac{\mathrm{RT}}{\mathrm{Nh}}\right) \mathrm{e}^{\Delta \mathrm{S} / \mathrm{R}} \mathrm{e}^{-\Delta \mathrm{H} / \mathrm{RT}} \\
\mathrm{k}=(\mathrm{PZ}) \mathrm{e}^{-\mathrm{E}_{\mathrm{a}} / \mathrm{RT}}
\end{gathered}
$$

\section{EXPERIMENTAL}

$\alpha$-Amylase and soluble starch were purchased from Sigma Chemical Co., USA and Central Drug House Pvt. Ltd., Mumbai, India, respectively. Chitosan and Carrageenan from Himedia, India. All other chemicals used were of Analytical Grade.

Determination of optimum $\mathbf{p H}$ and temperature: To determine the optimum $\mathrm{pH}$ for maximum enzyme activity, the reaction was carried out at different $\mathrm{pH}$ using $0.2 \mathrm{M}$ acetate buffer of $\mathrm{pH}$ 3.6, 4.0, 4.4, 4.8, 5.0, 5.2 and 5.6. Triplicate sets of seven tests tubes were arranged and $0.5 \mathrm{~mL}$ enzyme solution was added to each test tube containing $1.75 \mathrm{~mL}$ of starch, $2.25 \mathrm{~mL}$ of buffer ( $\mathrm{pH}$ range 3.6, 4.0, 4.4, 4.8, 5.0, 5.2 and 5.6) and $1 \mathrm{~mL}$ of distilled water. All the test tubes were incubated at $40{ }^{\circ} \mathrm{C}$ in a thermostatic water bath. After $20 \mathrm{~min}$, $0.5 \mathrm{~mL}$ of $1 \mathrm{M} \mathrm{HCl}$ was added to each test tube to stop the reaction. $0.2 \mathrm{~mL}$ of the reaction mixture from each test tube was diluted with $14.5 \mathrm{~mL}$ with distilled water. Then $0.2 \mathrm{~mL}$ of iodine reagent and $0.1 \mathrm{~mL}$ of $1 \mathrm{M} \mathrm{HCl}$ were added to each of them. The absorbance of the reaction mixture was recorded at $610 \mathrm{~nm}$ in a UV-visible spectrophotometer (Shimadzu UV1800) against a blank ${ }^{11-15}$.

Optimum temperature of the enzyme was determined by above procedure using buffer of optimum $\mathrm{pH}$ (5) and incubating at different temperatures viz. 30, 35, 40, 45, 50, 55 and $60{ }^{\circ} \mathrm{C}$ using a thermostatic water bath.

Immobilization of $\boldsymbol{\alpha}$-amylase with carrageenan: Mixture of $0.5 \mathrm{~mL} 1 \% \alpha$-amylase and $1.5 \mathrm{~mL} 3 \%$ carrageenan was transferred in drop wise manner from a height of about $2 \mathrm{~cm}$ in a stirred solution of $3.5 \% \mathrm{KCl}$ using a $2 \mathrm{~mL}$ pipette. The beads were kept for $0.5 \mathrm{~h}$ in $\mathrm{KCl}$ solution for hardening and then filtered and washed with acetate buffer ${ }^{16}$.

Immobilization of $\boldsymbol{\alpha}$-amylase with Chitosan: $0.5 \mathrm{~mL}$ of enzyme solution was mixed with $1.5 \mathrm{~mL}$ of $3 \%$ Chitosan solution and mixed thoroughly. The chitosan-enzyme mixture was transferred in dropwise manner from a height of about $2 \mathrm{~cm}$ in a gently stirred solution of $3 \mathrm{M} \mathrm{KOH}$ using a $2 \mathrm{~mL}$ pipettes. The beads were kept for $0.5 \mathrm{~h}$ in $\mathrm{KOH}$ solution for hardening which were then filtered and washed with acetate buffer at $\mathrm{pH} 5^{17}$.

Kinetic study: Triplicate sets of six test tubes were taken, each containing $2.25 \mathrm{~mL}$ of acetate buffer ( $\mathrm{pH} 5.0), 1 \mathrm{~mL}$ of distilled water and $1.75 \mathrm{~mL}$ of different concentration viz. 2.4, 2.0, 1.6, 1.2, 0.8 and $0 \%$ (blank) of soluble starch and maintained at $35^{\circ} \mathrm{C}$ in a thermostatic water bath. To each test tube $0.5 \mathrm{~mL} 1 \%$ amylase solution was added. After $10 \mathrm{~min}$, reaction in each test tube was stopped by addition of $0.5 \mathrm{~mL}$ of $1 \mathrm{M}$ $\mathrm{HCl} .0 .2 \mathrm{~mL}$ of the reaction mixture was diluted by addition of $14.5 \mathrm{~mL}$ distilled water followed by addition of $0.2 \mathrm{~mL}$ of $2 \%$ iodine reagent and $0.1 \mathrm{~mL}$ of $1 \mathrm{M} \mathrm{HCl}$. The absorbance was measured at $610 \mathrm{~nm}$ in a UV-visible spectrophotometer. The above procedure was repeated at 40 and $45^{\circ} \mathrm{C}$.
Above procedure was repeated for the kinetic study of immobilized enzyme but instead of using $0.5 \mathrm{~mL}$ free enzyme, carrageenan or chitosan immobilized enzyme beads prepared from $0.5 \mathrm{~mL} 1 \%$ enzyme were used.

Self-life: Self-life of the entrapped $\alpha$-amylase in carrageenan beads and Chitosan beads were evaluated by reusing the beads for digestion of starch $(1.2 \%)$ at $\mathrm{pH} 5$ and temperature $40{ }^{\circ} \mathrm{C}$ on 6 th and 12 th day. The beads were also inspected visually for any sign of physical change.

\section{RESULTS AND DISCUSSION}

Enzyme activities at different $\mathrm{pH}$ and temperature are plotted in Figs. 1 and 2 and optimum $\mathrm{pH}$ and temperature were found to be 5.0 and $40{ }^{\circ} \mathrm{C}$, respectively.

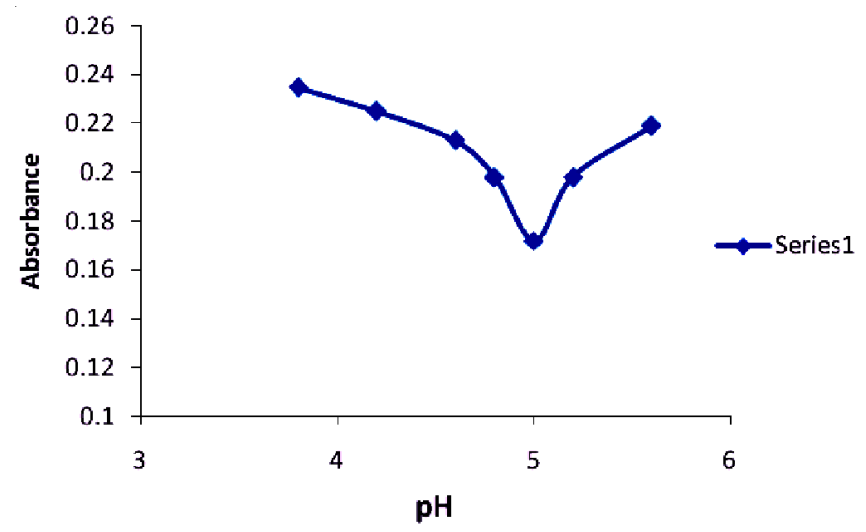

Fig. 1. Activity of $\alpha$-amylase at different $\mathrm{pH}$

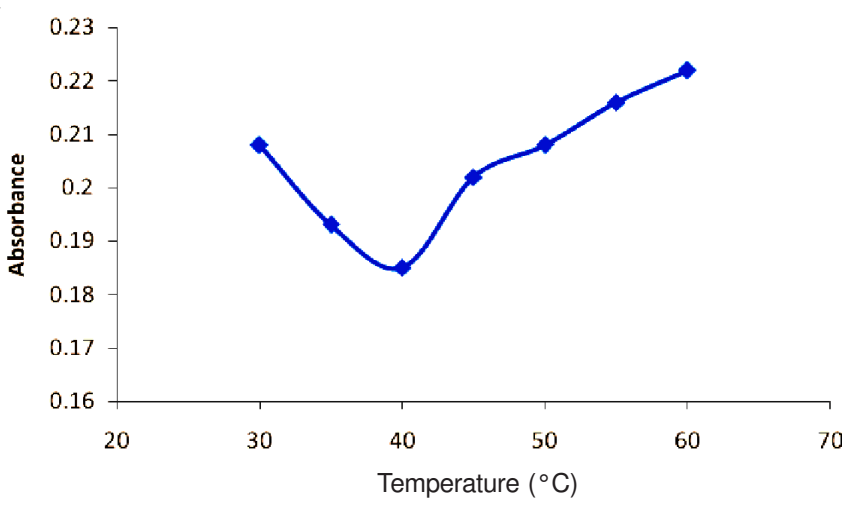

Fig. 2. Activity of $\alpha$-amylase at different incubation temperature

The starch degradation activities of free $\alpha$-amylase, carrageenan immobilized and chitosan immobilized enzyme at different temperature using different concentration of substrate are presented in Tables 1-3, respectively. The reciprocal velocity $(1 / \mathrm{V})$ at optimum temperature $40{ }^{\circ} \mathrm{C}$ was plotted against reciprocal substrate concentration (1/[S]) in Figs. 3, 5 and 7, respectively. Extrapolation of the line gave the $\mathrm{K}_{\mathrm{m}}$ values which are found to be $0.37,0.48$ and $0.59 \%$, respectively.

The $\mathrm{K}_{\mathrm{m}}$ value of the free enzyme is lower than that of the values of carrageenan or chitosan immobilized enzyme. Low value of $K_{m}$ indicate high affinity of the enzyme for the substrate $^{13}$. The increase in $\mathrm{K}_{\mathrm{m}}$ value might be either due to structural changes in the enzyme induced by the immobilization technique or due to lower accessibility of the substrate to the active site of the immobilized enzyme ${ }^{14}$. 


\begin{tabular}{|c|c|c|c|c|}
\hline \multicolumn{5}{|c|}{$\begin{array}{l}\text { TABLE-1 } \\
\text { STARCH DEGRADATION ACTIVITY OF FREE } \alpha \text {-AMYLASE }\end{array}$} \\
\hline \multirow{3}{*}{ Temp. $\left({ }^{\circ} \mathrm{C}\right)$} & \multicolumn{4}{|c|}{ Conc. of soluble starch $(\% \mathrm{w} / \mathrm{v})$} \\
\hline & 1.6 & 1.2 & 0.8 & 0.4 \\
\hline & \multicolumn{4}{|c|}{ Absorbance } \\
\hline 45 & $0.655 \pm 0.002$ & $0.439 \pm 0.006$ & $0.249 \pm 0.022$ & $0.125 \pm 0.002$ \\
\hline 40 & $0.617 \pm 0.002$ & $0.386 \pm 0.008$ & $0.200 \pm 0.013$ & $0.113 \pm 0.014$ \\
\hline 35 & $0.628 \pm 0.002$ & $0.400 \pm 0.002$ & $0.215 \pm 0.012$ & $0.120 \pm 0.006$ \\
\hline
\end{tabular}

TABLE-2

STARCH DEGRADATION ACTIVITY OF IMMOBILIZED $\alpha$-AMYLASE IN CARRAGEENAN

\begin{tabular}{ccccc}
\multicolumn{5}{c}{ STARCH DEGRADATION ACTIVITY OF IMMOBILIZED $\alpha$-AMYLASE IN CARRAGEENAN } \\
\cline { 2 - 5 } Temperature $\left({ }^{\circ} \mathrm{C}\right)$ & \multicolumn{5}{c}{ Conc. of soluble starch $(\% \mathrm{w} / \mathrm{v})$} \\
\cline { 2 - 5 } & \multicolumn{5}{c}{1.6} & 0.8 & 0.4 \\
\cline { 2 - 5 } & $0.766 \pm 0.003$ & $0.542 \pm 0.005$ & $0.327 \pm 0.014$ & $0.164 \pm 0.002$ \\
45 & $0.724 \pm 0.005$ & $0.474 \pm 0.006$ & $0.259 \pm 0.006$ & $0.145 \pm 0.014$ \\
35 & $0.742 \pm 0.010$ & $0.497 \pm 0.022$ & $0.284 \pm 0.012$ & $0.157 \pm 0.008$ \\
\hline Values are mean $\pm \mathrm{SD}(\mathrm{n}=3)$.
\end{tabular}

STARCH DEGRADATION ACTIVITY OF IMMOBILIZED $\alpha$-AMYLASE IN CHITOSAN

\begin{tabular}{ccccc} 
& \multicolumn{5}{c}{ TABLE-3 } \\
& \multicolumn{5}{c}{ STARCH DEGRADATION ACTIVITY OF IMMOBILIZED $\alpha$-AMYLASE IN CHITOSAN } \\
\hline \multirow{3}{*}{ Temperature $\left({ }^{\circ} \mathrm{C}\right)$} & \multicolumn{5}{c}{ Conc. of soluble starch $(\% \mathrm{w} / \mathrm{v})$} \\
\cline { 2 - 5 } & \multicolumn{5}{c}{ Absorbance } & 0.8 \\
\cline { 2 - 5 } & $0.809 \pm 0.004$ & $0.576 \pm 0.007$ & $0.362 \pm 0.012$ & $0.176 \pm 0.002$ \\
45 & $0.765 \pm 0.006$ & $0.510 \pm 0.007$ & $0.289 \pm 0.003$ & $0.159 \pm 0.014$ \\
35 & $0.783 \pm 0.004$ & $0.528 \pm 0.002$ & $0.311 \pm 0.014$ & $0.169 \pm 0.022$ \\
\hline Values are mean $+\mathrm{SD}(\mathrm{n}=3)$ & & &
\end{tabular}

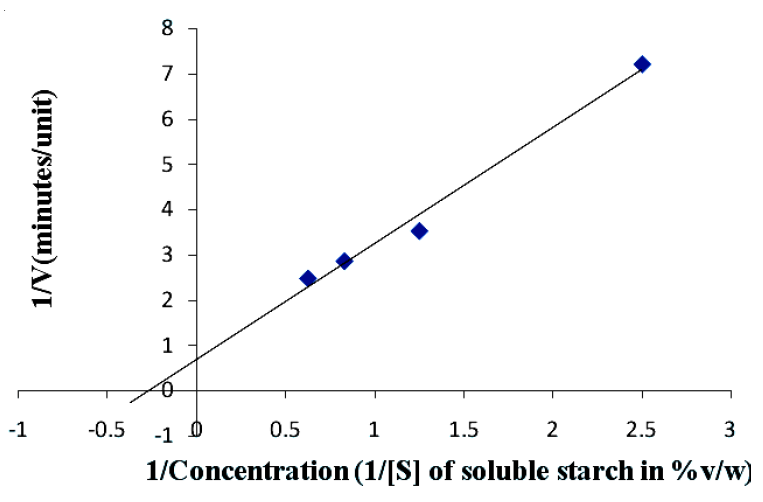

Fig. 3. Lineweaver burk plot of $\alpha$-amylase (free)

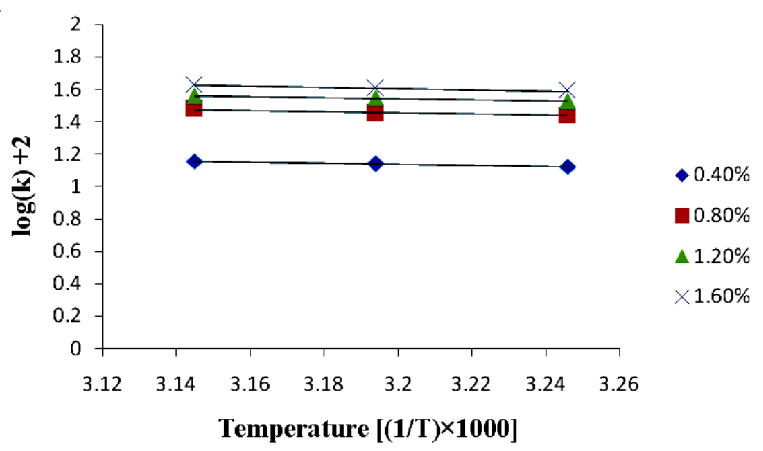

Fig. 4. Arrhenius plot of free enzyme ( $\alpha$-amylase)

Arrhenius plot of the free and immobilized enzyme are presented in Figs. 4, 6 and 8, respectively and from the slope, energy of activation $\left(E_{a}\right)$ was calculated for each case. Subsequently, Gibbs free energy $\left(\Delta \mathrm{G}^{\mathrm{o}}\right)$ entropy of activation $(\Delta \mathrm{S})$

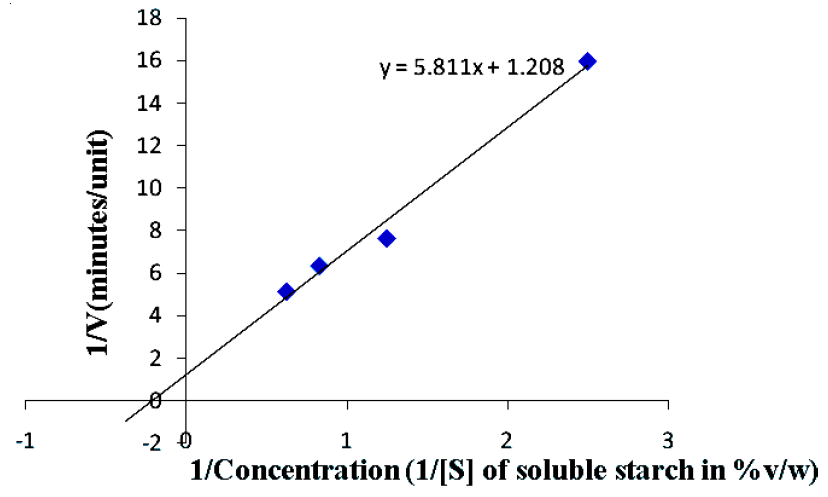

Fig. 5. Lineweaver burk plot of $\alpha$-amylase immobilized in carrageenan

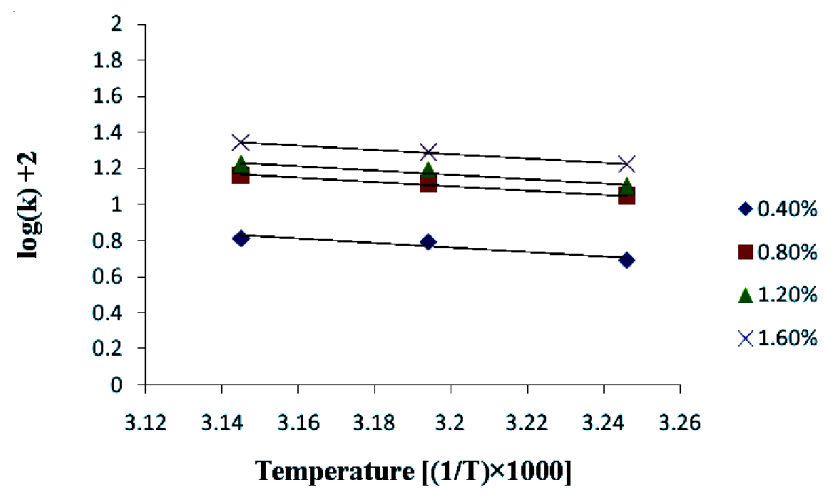

Fig. 6. Arrhenius plot of $\alpha$-amylase immobilized in carrageenan

equilibrium constant $(\mathrm{k})$, probability factor $(\mathrm{P})$ for free and immobilized enzyme were computed using above mentioned equations and are presented in Table-4. 
TABLE-4

COMPUTED DATA

\begin{tabular}{lccccccc}
\hline \multicolumn{1}{c}{ Enzyme } & $\mathrm{E}_{\mathrm{a}}$ or $\Delta \mathrm{H}(\mathrm{cal} / \mathrm{mol})$ & $\mathrm{A}\left(\mathrm{s}^{-1}\right)$ & $\Delta \mathrm{S}(\mathrm{cal} / \mathrm{mol})$ & $\Delta \mathrm{G}^{\mathrm{o}}$ & $\mathrm{K}$ & $\mathrm{K}_{\mathrm{m}}(\% \mathrm{w} / \mathrm{v})$ & $\mathrm{P}$ \\
\hline$\alpha$-Amylase (free) & 1536 & $1.62 \times 10^{2}$ & -48.52 & 16722 & $2.119 \times 10^{-12}$ & 0.37 & $2.490 \times 10^{-11}$ \\
Immobilized in carrageenan & 5463.8 & $3.84 \times 10^{4}$ & -37.6 & 17232 & $9.240 \times 10^{-13}$ & 0.48 & $5.900 \times 10^{-9}$ \\
Immobilized in chitosan & 4736 & $9.93 \times 10^{3}$ & -40.34 & 17363 & $7.51 \times 10^{-13}$ & 0.59 & $1.524 \times 10^{-9}$ \\
\hline
\end{tabular}

\section{TABLE-5}

STARCH DEGRADATION ACTIVITIES OF IMMOBILIZED $\alpha$-AMYLASE AT

OPTIMUM PH AND TEMPERATURE AFTER DIFFERENT TIME OF STORAGE

\begin{tabular}{lccc}
\hline \multicolumn{1}{c}{ Enzyme } & Absorbance on 1st day & Absorbance on 6th day & Absorbance on 12th day \\
\hline Carrageenan immobilized $\alpha$-amylase & $0.474 \pm 0.006$ & $0.496 \pm 0.002$ & $0.510 \pm 0.006$ \\
Chitosan immobilized $\alpha$-amylase & $0.483 \pm 0.007$ & $0.510 \pm 0.003$ & $0.514 \pm 0.006$ \\
\hline Values are mean \pm SD $(n=3)$. & & &
\end{tabular}

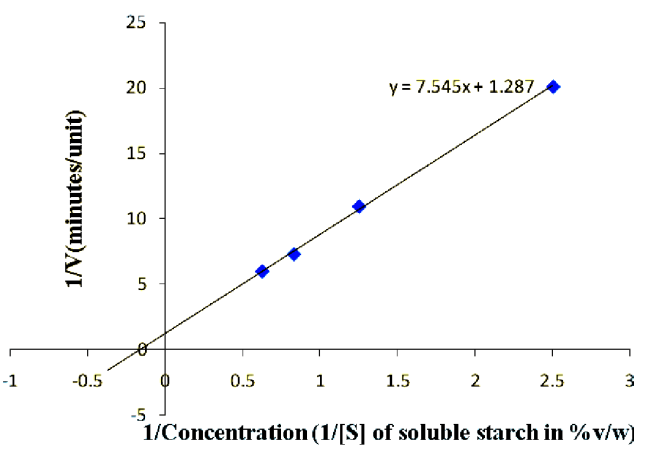

Fig. 7. Lineweaver burk plot of $\alpha$-amylase immobilized in chitosan

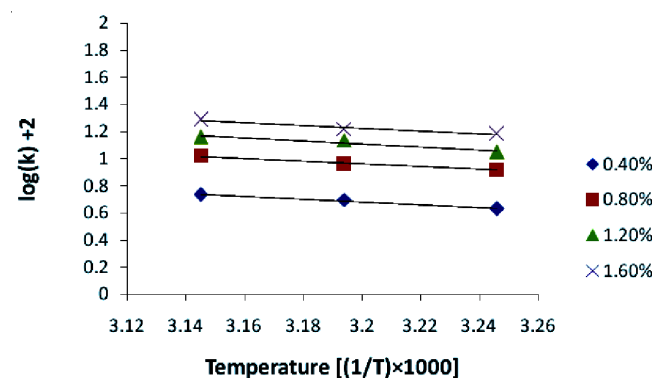

Fig. 8. Arrhenius plot of $\alpha$-amylase immobilized in chitosan

Lower the entropy values of the enzyme, more efficient are the formation of transition state or activated complex between enzyme-substrate ${ }^{18}$. The present study showed the lower entropy value for the free enzyme but higher entropy value for the immobilized enzyme indicating the good efficiency in the formation of transition state for free enzyme in comparison to immobilized enzyme. Computed $\Delta \mathrm{S}$ value for free enzyme $(-48.52 \mathrm{cal} / \mathrm{mol}-\mathrm{deg})$ is more negative than the carrageenan immobilized beads $(-37.6 \mathrm{cal} / \mathrm{mol}-\mathrm{deg})$ or chitosan immobilized beads ( $-40.34 \mathrm{cal} / \mathrm{mol}-\mathrm{deg})$.

The reaction rate is proportional to formation of transition state complex by lowering the Gibb's Free Energy of activation $\left(\Delta \mathrm{G}^{\mathrm{o}}\right)$. The increasing value of $\Delta \mathrm{G}^{\mathrm{o}}$ in immobilized enzyme (17232 cal/mol for carrageenan immobilized and $17363 \mathrm{cal} /$ mol for chitosan immobilized) than in free form $(16722 \mathrm{cal} /$ $\mathrm{mol}$ ) indicates that the enzyme substrate reaction is slower during immobilization.

$\mathrm{K}$ value for free enzyme $\left(2.119 \times 10^{-12}\right)$ is more than that of carrageenan immobilized or chitosan immobilized enzyme $\left(9.240 \times 10^{-13}\right.$ and $7.51 \times 10^{-13}$, respectively) which indicated that free enzyme was more specific than immobilized enzyme. Starch degradation activities of immobilized enzyme after different time of storage are presented in Table-5. It is evident from the table that the immobilized enzyme retained is activity even after 12 days. However the beads developed small fissure or softened or partially broken in the reaction mixture after more than 12 days storage.

Immobilized enzymes are generally more stable compared to free enzymes, due to the curtailment of their degrees of freedom of rotation. Entrapped enzymes are unable to rotate freely. Prevention of the unfolding of its structure could be preserving its function ${ }^{19}$. The present work demonstrated a promising application potential of the carrageenan and chitosan beads for enzyme immobilization.

\section{REFERENCES}

1. A.L. Smith, Oxford Dictionary of Biochemistry and Molecular Biology, Oxford University Press, p. 43 (1997).

2. C.M. Grisham and R.H. Garrett, Biochemistry, Saunders College Publ., Philadelphia, edn 2, p. 426 (1999).

3. R.A. Messing, J. Am. Chem. Soc., 91, 2370 (1969).

4. W.L. Stanley and A.C. Olson, US Patent, 736,231 (1973).

5. G.R. Stark, Biochemical Aspects of Reactions on Solid Supports, Academic Press, New York (1971).

6. W. Gaffield, Y. Tomimatsu, A.C. Olson and E.F. Jansen, Arch. Biochem. Biophys., 157, 405 (1973).

7. P. Bernfeld and J. Wan, Science, 142, 678 (1963).

8. T. Yamamoto, Bacterial $\alpha$-amylase (liquefying and saccharifying types) of Bacillus subtilis and related bacteria. In: The Amylase Research Society of Japan, Handbook of amylase and related enzymes. Their sources, isolation methods, properties and applications, pp. 40-45 Pergamon Press, Oxford (1988).

9. D.A. Fell, Understanding the Control of Metabolism, Portland Press, London (1997).

10. R.N. Goldberg, Y.B. Tewari, D. Bell, K. Fazio and E. Anderson, J. Phys. Chem. Ref. Data, 22, 515 (1993).

11. A. Tanaka and E. Hoshino, J. Biosci. Bioeng., 96, 262 (2003).

12. G. Dey, B. Singh and R. Banerjce, Braz. Arch. Biol. Technol., 46, 167 (2003).

13. L.M. Hamilton, C.T. Kelly and W.M. Fogarty, Carbohydr. Res., 314, 251 (1998)

14. J.F. Kennedy, E.H.M. Melo and K. Jumel, Chem. Eng. Prog., 45, 81 (1990).

15. S. Pramanik, K.K. Sarwa, A.K. Dolui and A. Kumar, Asian J. Chem., 25, 6557 (2013).

16. B. Krajewska, Enzym. Microbiol. Technol., 35, 126 (2004).

17. S. Anisworth, University Park press, London, England, p. 43 (1977).

18. M. Riaz, R. Perveen, M.R. Javed, H. Nadeem and M.H. Rashi, Enzym. Microbiol. Technol., 41, 558 (2007).

19. R.S.S. Kumar, K.S. Vishwanath, S.A. Singh and A.G.A. Rao, Proc. Biochem., 41, 2282 (2006). 